Double Helix, Vol 3 (2015)

\title{
Beyond the Two Cultures
}

\author{
Justin Hayes, Paul Pasquaretta, and Glenda Pritchett \\ Quinnipiac University
}

In his 1959 Rede Lecture, "The Two Cultures and the Scientific Revolution," C. P. Snow warned of a gulf that had opened between literary intellectuals and natural scientists, across which existed a mutual incomprehension that threatened to undermine the university's ability to solve the world's most pressing problems. Reflecting on his experience as both a novelist and a research scientist, Snow appealed for a greater understanding between what he saw as two distinct cultures, yet he also asserted the importance of the sciences over literature for securing humanity's future prosperity. According to Snow, literary intellectuals were natural Luddites, and the university needed to prioritize the training of scientists and engineers in order to accelerate global industrialization and thereby raise standards of living. His privileging of the sciences drew a scathing rebuke from the literary critic F. R. Leavis, who pilloried Snow's understanding of literature and his faith in technological progress. For Leavis, bringing the Industrial Revolution to impoverished areas of the globe could indeed improve the material conditions of humankind, but such a project ungoverned by the values conveyed through literature, especially those insights of $D$. $H$. Lawrence and other novelists into the dehumanizing effects of industrial labor, would lead to a future divested of any real quality of life. Leavis insisted, therefore, that the university revolve around English studies as its "centre of human consciousness" (2013, p. 75).

This dispute between Snow and Leavis touched off "the two cultures controversy," which has been an important point of reference amid the shifting terrain of higher education. The phrase has come to denote a gulf that opens between any disciplines bound to "common attitudes, common standards and patterns of behavior, common approaches and assumptions" (Snow, 1998, p. 9) that divide them into opposing cultures and inhibit crossdisciplinary understanding. Buller (2014), for example, described the two cultures in terms of those who believe the purpose of colleges and universities is to educate "the whole person" versus those who believe it is to train students for the workforce. The latter culture, according to Buller, tends to include governors, legislators, and trustees who are inclined to divert resources away from the social sciences, arts, and humanities to science, technology, engineering, and mathematics. Their assumption is that the STEM disciplines will best prepare students for careers offering the greatest return on their investment in a college education. The opposing culture, most often composed of faculty and administrators, argues that a well-rounded education produces graduates who are better informed, challenge assumptions more readily, participate more fully in society and civil discourse, and in general live healthier and more productive lives. Buller observed that "the two sides are not so much talking to one another as shouting past one another, each contingent building its case on a set of assumptions that it regards as universally true and that is dismissed by its opponents as the result of blindness, hypocrisy, or both" (p. 2). This situation stands in contrast to the lack of engagement Halsted (2015) observed between the culture of academia and that of the tech industry. He pointed out that although a number of the most significant 
advances in information technology began in university laboratories and computer centers, academia has increasingly been displaced by startup companies as the primary sites of innovation. The culture of academia, Halsted argued, retains its medieval guild mentality, with its emphasis on hierarchy, credentialing, and protectionism, which impede the creativity and problem-solving facilitated by tech culture through its horizontal collaboration, inclusivity (college dropouts are among the industry's leaders), and open competition. At the same time, programmers, Halsted suggested, have limited knowledge of history, literature, and the arts, which can hinder their understanding of the social contexts within which their software and devices are used and thereby curb their potential for improving designs and developing new applications.

Although the two cultures controversy is most often cast as a quandary over how knowledge is to be recognized and valued, it is addressed more radically in Volume 3 of Double Helix as a problem of pedagogy. The authors, in sharing their insights into how critical thinking and writing can be taught in and across disciplines, also invite us, implicitly and explicitly, to think critically about our own attitudes, standards and patterns of behavior, approaches and assumptions that define our respective cultures and, when otherwise unexamined, perpetuate a lack of comprehension across disciplines. The authors not only suggest how the gulf between two cultures may be closed to establish a common ground of cross-disciplinary understanding but also prompt us to consider how we might cultivate this ground to advance higher education beyond recurring controversies to more continuous and constructive dialogue that will someday transpire between our students as the professors, administrators, government officials, trustees, industry leaders, and others deciding the future of the university.

\section{References}

Buller, J. L. (2014). The two cultures of higher education in the twenty-first century and their impact on academic freedom. AAUP Journal of Academic Freedom, 5, 1-8. Retrieved from http://www.aaup.org/file/Buller.pdf

Halsted, D. G. (2015, March 24). The two cultures, 2.0. Inside Higher Ed. Retrieved from https://www.insidehighered.com/views/2015/03/24/essay-divide-between-faculty-members-and-ed-tech-industry

Leavis, F. R. (2013). Two cultures? The significance of C. P. Snow. Cambridge, United Kingdom: Cambridge University Press.

Snow, C. P. (1998). The two cultures. Cambridge, United Kingdom: Cambridge University Press. 